\title{
PENINGKATAN ADAPTABILITAS DAN PERTUMBUHAN BEBERAPA VARIETAS PADI GOGO MELALUI INOKULASI PUPUK HAYATI DAN BIOKOMPOS DI KAWASAN PESISIR
}

\author{
Improving Adaptability and Growth of Upland Rice Varieties through Biological Fertilizer \\ Inoculation and Biocompost in Coastal Area
}

\author{
Yudhi Harini Bertham, Abimanyu Dipo Nusantara, \\ Bambang Gonggo Murcitro*, dan Zainal Arifin \\ Program Studi Ilmu Tanah, Fakultas Pertanian,Universitas Bengkulu \\ Jl. Raya W.R. Supratman, Kandanglimun, Bengkulu. 38371
}

Alamat korespondensi: bgonggo@unib.ac.id

\begin{abstract}
ABSTRAK
Pemanfaatan lahan kering pada kawasan pesisir untuk budidaya tanaman padi gogo mempunyai potensi besar untuk pemantapan swasembada pangan maupun untuk pembangunan pertanian kedepan. Keterbatasan kesuburan yang dimiliki lahan di kawasan pesisir dapat diatasi dengan menggunakan teknologi yang tepat seperti penggunaan varietas yang unggul dan pupuk hayati serta biokompos. Penelitian ini bertujuan untuk mengetahui karakteristik biologi dan kimia tanah serta pertumbuhan padi gogo di kawasan pesisir. Rancangan percobaan yang digunakan adalah rancangan petak terbagi dengan petak utama adalah 3 varietas padi gogo yang didapatkan dari BPTP Bengkulu yaitu varietas Inpago 10, Serantan, dan Lokal Bengkulu, dengan anak petak yaitu inokulan ganda mikroba pelarut $\mathrm{P}(\mathrm{pf})+$ mikroba pelarut $\mathrm{K}+$ mikroba pemfiksasi $\mathrm{N}$, inokulan ganda mikroba pelarut $\mathrm{P}(\mathrm{fma})+$ mikroba pelarut $\mathrm{K}+$ mikroba pemfiksasi $\mathrm{N}$, biokompos dengan dosis 10 ton $\mathrm{ha}^{-1}$, dan pupuk anorganik rekomendasi BPTP yaitu $200 \mathrm{~kg}$ Urea/ha, $100 \mathrm{~kg} \mathrm{SP36} / \mathrm{ha}, 100 \mathrm{~kg} \mathrm{KCl} / \mathrm{ha}$, diulang 4 kali. Hasil penelitian menunjukkan bahwa aplikasi pupuk hayati maupun biokompos yang ditanami padi gogo varietas Inpago 10 di area pesisir mampu meningkatkan karakter biologi dan kimia tanah. Padi gogo varietas Serantan dengan aplikasi inokulan ganda mikroba pelarut $\mathrm{P}+$ mikroba pelarut $\mathrm{K}+$ mikroba pemfiksasi $\mathrm{N}$ di area pesisir mampu menghasilkan jumlah anakan tinggi dengan tinggi tanaman rendah
\end{abstract}

Kata kunci: adaptabilitas, lahan pesisir, padi gogo, pertumbuhan, pupuk hayati.

\section{ABSTRACT}

Utilization of dry land in coastal areas for the cultivation of upland rice has great potential for the stabilization of food self-sufficiency and for future agricultural development. Limitations of fertility owned by land in coastal areas can be overcome by using appropriate technology such as the use of superior varieties and biofertilizers and biocompost. This study aims to know soil biology and chemistry characters, and the growth of upland rice in the coastal area. The experimental design used was a split plot design with the main plot of upland rice variety consisted of Inpago 10, Serantan, and Bengkulu Local, and subplots of fertilizer inputs consisted of double inoculant microbial solvent $P(p f)+$ microbial solvent $K+$ microbial fixation $N]$, double inoculant microbial solvent $P(\mathrm{fma})+$ microbial solvent $K+$ microbial fixator $N]$, biocompost at a dose of 10 tons $/$ ha, and

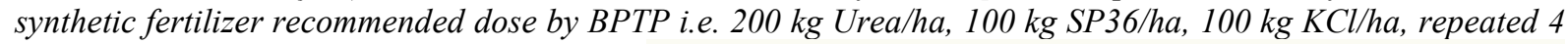
times. The results showed that application of inoculants of biological fertilizer in coastal area grown by Inpago 10 improved soil biology and chemistry characters. Serantan variety with application of double inoculant microbial solvent $P+$ microbial solvent $K+$ microbial $N$ fixation gained the high tillers number with low plant height.

Keywords: adaptability, biocompost, coastal land, growth, upland rice.

\section{PENDAHULUAN}

Indonesia memiliki panjang pantai terpanjang kedua di dunia yaitu sekitar $81.000 \mathrm{~km}$ dengan luas laut 5,8 juta $\mathrm{km}^{2}$
(Budiharsono, 2001). Lahan pesisir mempunyai karakter yang tidak mendukung bagi tanaman karena kadar garam tinggi sehingga menyebabkan 
tekanan osmotik meningkat yang menyebabkan tanaman mengalami cekaman kekeringan, toksinitas ion seperti ion-ion $\mathrm{Cl}^{-}$dan $\mathrm{Na}^{+}$yang berlebihan, dan ketidakseimbangan unsur hara akibat penghambatan penyerapan nutrisi, serta kombinasi dari faktor-faktor tersebut (Ashraf and Harris, 2004; Gorham, 2007). Pemanfaatan lahan pesisir khususnya di Provinsi Bengkulu masih sangat terbatas, karena keterbatasan teknologi dan varietas untuk mengatasi masalah tersebut (Nurmegawati dan Wibawa, 2012). Sejauh ini, beberapa peneliti telah berhasil membudidayakan tanaman pada lahan pesisir di Bengkulu diantaranya yaitu cabai organik (Bertham et al., 2013), Gembili (Heriso et al., 2015), Kacang Tanah (Bertham dan Nusantara, 2017), Kedelai (Bertham et al., 2016, 2017, dan 2018), edamame (Nusantara et al., 2018), dan Talas (Simamora et al., 2018).

Lahan pesisir memiliki potensi sebagai lahan budidaya jika menggunakan teknologi yang tepat. Salah satu teknologi yang dapat diterapkan yaitu dengan memperbaiki sifat tanah pesisir dengan memanfaatkan mikroba tanah yang ada di kawasan pesisir (in situ) seperti fungi mikoriza arbuskula, bakteri pelarut phospat, mikroba pelarut $\mathrm{K}$ dan azotobakter. Pemanfaatan mikroorganisme merupakan metode yang aman dan efektif untuk digunakan pada tanah pasir. Tanah pasir umumnya bersifat sangat porous sehingga penggunaan pupuk kimia akan sangat mudah tercuci dan hilang dari area perakaran. Pemberian pupuk kimia pada tanah-tanah pasir umumnya tidak efektif dan mudah hilang melalui perkolasi dan pelindian unsur hara. Penggunaan mikroorganisme tanah pada tanah pasir diharapkan dapat memperbaiki sifat-sifat tanahnya. Menurut Sudaryono (2001) keberadaan mikroba didalam tanah memegang peranan penting dalam transformasi perubahan sifat biologi dan kimia tanah.

Fungi mikoriza arbuskula merupakan tipe endomikoriza yang menyediakan unsur P menjadi tersedia bagi tanaman dikarenakan peran dari enzim fosfatase (Oktaviani et al., 2014). Menurut Zuhry dan Puspita (2008), FMA dapat meningkatkan kemampuan akar dalam menyerap hara dan air untuk menunjang pertumbuhan dan perkembagan tanaman. Nurhayati (2012) menambahkan bahwa fungsi utama hifa adalah untuk menyerap air dari dalam tanah, P yang terakumulasi pada hifa eksternal akan segera diubah menjadi senyawa polifosfat dengan adanya enzim fosfatase. Selain itu hasil penelitian Bertham (2002) menunjukan bahwa mikoriza mampu melepaskan asam-asam organik sehingga terjadi peningkatan $\mathrm{pH}$.

Bakteri pelarut fosfat (BPF) merupakan salah satu mikroorganisme 
tanah yang mampu melarutkan ion $\mathrm{P}$ yang terikat dengan kation tanah berupa $\mathrm{Al}, \mathrm{Fe}$, $\mathrm{Ca}$, dan $\mathrm{Mg}$ kemudian mengubahnya menjadi bentuk tersedia untuk diserap tanaman secara alam (Keneni et al., 2010). Bakteri pelarut fosfat mampu mensekresikan enzim fosfatase yang berperan dalam proses hidrolisis $\mathrm{P}$ organik menjadi $\mathrm{P}$ anorganik dan juga bakteri pelarut fosfat dapat menghasilkan zat pengatur tumbuh (Purwaningsih, 2003). Hasil penelitian Astuti et al. (2013) menunjukkan bahwa bakteri pelarut fosfat (BPF) mampu dalam meningkatkan bobot basah, tinggi, kadar nitrogen $(\mathrm{N})$ dan kadar fosfor (P) tanaman tomat pada tanah masam.

Mikroba pelarut kalium dapat melarutkan kalium dari ikatan kalium tak larut pada suatu media melalui sekresi asam-asam organik dan mikroba pelarut kalium dapat memanfaatkan kalium terlarut pada suatu media untuk pembentukan selsel baru, sehingga terjadi pengikatan (immobilisasi) kalium oleh mikroba (Basak and Biswas, 2009). Beberapa kelompok bakteri pelarut $\mathrm{K}$ diketahui mampu melarutkan K seperti Pseudomonas, Burkholderia, Azotobacter, Rhizobium, Bacillus, dan Paenibacillus (Hu et al., 2006; Singh et al., 2010; Don and Diep, 2014).

Azotobacter adalah spesies rizobakteri yang telah dikenal sebagai agen biologis penambat $\mathrm{N} 2$ diazotrof, yang menkonversi dinitrogen ke amonium melalui reduksi elektron dan protonasi gas dinitrogen. Azotobacter vinelandii adalah bakteri gram-negatif yang mengikat nitorgen menggunakan nitrogenase holoenzyme yang memiliki kofaktor klaster molibdenum besi sulfat (FeMoCo) sebagai lokasi aktif (Chiu et al., 2001). Azotobacter hidup bebas sebagai saprofit di tanah, air tawar, lingkungan laut dan habitat alam lainnya dan telah digunakan sebagai inokulum efektif untuk meningkatkan pertumbuhan tanaman dan pengendalian hama (Aquilanti et al., 2004).

Padi gogo merupakan salah satu tanaman pangan yang berpotensi dikembangkan pada lahan kering di kawasan pesisir. Produksi padi 2016 sebesar 79.355.000 ton dengan luas panen 15.755.000 ha (produktivitas 5,236 ton/ha), yang terbagi atas produksi padi sawah sebesar 75.483.000 ton dengan luas area 14.633.000 ha (produktivitas 5,397 ton/ha) dan produksi padi darat sebesar 3.872.000 ton dengan luas area 1.171 .000 ha (produktivitas 3,307 ton/ha). Produksi padi 2017 sebesar 81.382.000 ton dengan luas panen 17.788.000 ha (produktivitas 5,155 ton/ha), yang terbagi atas produksi padi sawah sebesar 77.603.000 ton dengan luas area 14.633.000 ha (produktivitas 5,303 ton/ha) dan produksi padi darat sebesar 3.779.000 ton dengan luas area 1.156.000 
ha (produktivitas 3,270 ton/ha) (Kementerian Pertanian Republik Indonesia, 2017). Berdasarkan data tersebut maka terdapat penurunan produksi padi darat pada tahun 2017 yaitu sebesar 2.400 ton, yang disebabkan oleh penurunan luas area panen sebesar 13.100 ha serta penurunan produktivitas sebesar 0,112 ton/ha.

Pemanfaatan lahan kering pada kawasan pesisir untuk budidaya tanaman padi gogo mempunyai potensi besar untuk pemantapan swasembada pangan maupun untuk pembangunan pertanian ke depan. Menurut Abdurachman et al. (2008) kebutuhan pangan selama ini ditunjang oleh padi sawah, yang dalam produksinya membutuhkan karakteristik lahan dengan tingkat kesuburan cukup tinggi. Karakteristik budidaya padi sawah yang demikian membatasi peluang peningkatan produksi beras melalui perluasan areal sawah. Hal ini karena sempitnya lahan cadangan yang sesuai untuk dijadikan sawah dan makin ketatnya persaingan penggunaan air dengan industri, pertambangan, dan rumah tangga.

Berdasarkan latar belakang diatas maka penelitian ini bertujuan untuk mengetahui karakteristik biologi dan kimia tanah serta pertumbuhan padi gogo di kawasan pesisir.

\section{METODE PENELITIAN}

Penelitian dilaksanakan pada bulan Juli 2019 sampai dengan Februari 2020 di Kelurahan Beringin Raya Kecamatan Muara Bangkahulu kota Bengkulu. Pembuatan inokulan pupuk hayati dilakukan di Laboratorium Biologi Tanah, Fakultas Pertanian Universitas Bengkulu. Sedangkan pengukuran bobot kering tanaman, analisis tanah awal dan akhir, serta kadar hara jaringan dilakukan di Laboratorium Ilmu Tanah, Fakultas Pertanian, Universitas Bengkulu.

$$
\text { Rancangan percobaan yang }
$$
digunakan adalah rancangan petak terbagi (Split plot design) dengan petak utama adalah 3 varietas padi gogo yang didapatkan dari BPTP Bengkulu yaitu varietas Inpago $10\left(\mathrm{~V}_{1}\right)$, varietas Serantan $\left(\mathrm{V}_{2}\right)$, dan varietas Lokal Bengkulu $\left(\mathrm{V}_{3}\right)$, sedangkan anak petaknya adalah input pupuk yaitu $\mathrm{P}_{1}$ [inokulan ganda mikroba pelarut $\mathrm{P}(\mathrm{pf})+$ mikroba pelarut $\mathrm{K}+$ mikroba pemfiksasi N], $\mathrm{P}_{2}$ [inokulan ganda mikroba pelarut $\mathrm{P}$ (fma) + mikroba pelarut $\mathrm{K}+$ mikroba pemfiksasi $\mathrm{N}$ ], $\mathrm{P}_{3}$ [biokompos dengan dosis 10 ton/ha], dan $\mathrm{P}_{4}$ [pupuk anorganik rekomendasi BPTP yaitu $200 \mathrm{~kg}$ Urea/ha, $100 \mathrm{~kg} \mathrm{SP36/ha,} 100 \mathrm{~kg} \mathrm{KCl} / \mathrm{ha}$ ]. Kedua faktor tersebut dikombinasikan sehingga terdapat 12 kombinasi perlakuan yang diulang 4 kali sehingga terdapat 48 satuan percobaan. Setiap unit percobaan terdiri atas 50 tanaman sehingga jumlah 
total populasi tanaman adalah $50 \times 48=$ 2.400 tanaman. Data yang diperoleh dianalisis menggunakan analisis ragam taraf 5\%. Variabel pengamatan yang menunjukan hasil berbeda nyata dianalisis lanjut dengan Duncan's Multiple Range Test (DMRT) taraf 5\%.

\section{HASIL DAN PEMBAHASAN}

Hasil analisis menunjukkan bahwa tanah pada lahan penelitian mengandung $0,19 \% \mathrm{~N}$ yang tergolong rendah, $0,23 \% \mathrm{C}$ organik yang tergolong sedang, 0,28 me $100 \mathrm{~g} \mathrm{tanah}^{-1} \mathrm{~K}_{2} \mathrm{O}$ yang tergolong rendah, 6,23 ppm $\mathrm{P}_{2} \mathrm{O}_{5}$ yang tergolong rendah, dengan nilai $\mathrm{pH} \mathrm{H}_{2} \mathrm{O}$ sebesar 6,2 yang tergolong agak masam, $\mathrm{pH} \mathrm{KCl} 5,8$ yang tergolong agak masam, KTK sebesar 5,21 me $100 \mathrm{~g} \mathrm{tanah}^{-1}$ yang tergolong rendah. Berdasarkan data tersebut maka dapat disimpulkan bahwa tanah yang berada pada lokasi penelitian tergolong marginal dengan permasalahan kadar unsur hara, bahan organik, dan KTK tergolong rendah, serta pH agak masam.

Perbaikan tanah dilakukan lebih pada menyeimbangkan kembali hubungan simbiosis mutualisme atau hubungan yang saling menguntungkan pada alam. Mikroorganisme tanah seperti azotobakter, fungi mikoriza arbuskular (FMA), bakteri pelarut fosfat (BPF), dan bakteri pelarut kalium (BPK) memiliki hubungan simbiosis mutualisme dengan tanaman berupa perbaiki kualitas kesuburan tanah. Dengan terjaganya kesuburan tanah maka daya ikat tanah terhadap air, terhadap unsur hara dan tanah sebagaisumber hidup utama tanaman akan terpenuhi. Hasil analisis varian menunjukkan bahwa perlakuan memberikan pengaruh nyata terhadap populasi Azotobakter dan populasi bakteri pelarut $\mathrm{K}$, namun memberikan pengaruh tidak nyata terhadap populasi FMA dan BPF.

Aplikasi inokulan ganda mikroba pelarut $\mathrm{P}(\mathrm{pf})+$ mikroba pelarut $\mathrm{K}+$ mikroba pemfiksasi $\mathrm{N}$ yang dikombinasikan dengan padi gogo varietas Inpago 10 menghasilkan populasi Azotobakter dan bakteri pelarut K lebih tinggi dibandingkan dengan perlakuan lainnya yaitu secara berturut-turut 25,87 koloni/g dan 120,03 koloni/g (Tabel 1). Hal ini mengindikasikan bahwa inokulan ganda pupuk hayati yang terdiri atas mikroba pelarut $\mathrm{P}(\mathrm{pf})+$ mikroba pelarut $\mathrm{K}+$ mikroba pemfiksasi $\mathrm{N}$ lebih cocok dengan rhizosfer varietas Inpago 10. Kualitas rizodeposisi (faktor yang mendorong kehadiran mikroba ke rizosfer) bergantung pada jenis tumbuhan (Jones et al., 2004; Bais et al., 2006). Rizodeposisi ini mengandung sel dan eksudat, gula, asam organik dan asam amino (Bertin et al., 2003) yang digunakan mikroba sebagai substrat sehingga populasi meningkat (Doornbos et al., 2012). 
Namun demikian, secara umum hasil penelitian menunjukkan bahwa populasi mikroorganisme tanah yang diamati pada rhizosfer tanaman yang diionulasi cenderung lebih tinggi dibandingkan dengan tanpa diinokulasi. Hal ini menunjukkan bahwa pada dasarnya lokasi penelitian yang digunakan memiliki karakteristik sifat biologi tanah yang kurang baik sehingga populasi mikroorganisme cenderung rendah. Oleh karena itu, dibutuhkan inokulasi untuk meningkatkan keragaman dan kuantitas mikroorganisme tanah.

Tabel 1. Pengaruh inokulasi pupuk hayati dan biokompos terhadap beberapa karakteristik biologi tanah

\begin{tabular}{ccccc}
\hline Perlakuan & $\begin{array}{c}\text { Populasi Azotobakter } \\
(\text { koloni/g) }\end{array}$ & $\begin{array}{c}\text { Populasi FMA } \\
\text { (koloni/g) }\end{array}$ & $\begin{array}{c}\text { Populasi BPF } \\
\text { (koloni/g) }\end{array}$ & $\begin{array}{c}\text { Populasi BPK } \\
\text { (koloni/g) }\end{array}$ \\
\hline V1P1 & $25,87 \mathrm{a}$ & 121,79 & 150,38 & $120,03 \mathrm{a}$ \\
V1P2 & $11,33 \mathrm{~b}$ & 169,23 & 166,03 & $119,87 \mathrm{a}$ \\
V1P3 & $3,21 \mathrm{c}$ & 127,44 & 122,95 & $15,77 \mathrm{c}$ \\
V1P4 & $2,56 \mathrm{c}$ & 124,36 & 136,28 & $11,28 \mathrm{c}$ \\
V2P1 & $18,33 \mathrm{a}$ & 138,85 & 136,92 & $62,18 \mathrm{~b}$ \\
V2P2 & $15,97 \mathrm{~b}$ & 155,13 & 127,56 & $55,77 \mathrm{c}$ \\
V2P3 & $4,78 \mathrm{c}$ & 135,90 & 150,64 & $25,77 \mathrm{c}$ \\
V2P4 & $1,92 \mathrm{c}$ & 127,56 & 133,46 & $13,85 \mathrm{c}$ \\
V3P1 & $20,44 \mathrm{a}$ & 146,79 & 126,28 & $118,33 \mathrm{a}$ \\
V3P2 & $16,03 \mathrm{a}$ & 162,18 & 152,82 & $106,54 \mathrm{a}$ \\
V3P3 & $4,21 \mathrm{c}$ & 166,92 & 128,72 & $23,85 \mathrm{c}$ \\
V3P4 & $3,85 \mathrm{c}$ & 140,51 & 133,97 & $24,49 \mathrm{c}$ \\
\hline
\end{tabular}

Keterangan: $\mathrm{FMA}=$ fungi mikoriza arbuskular, $\mathrm{BPF}=$ bakteri pelarut fosfat, dan $\mathrm{BPK}=$ bakteri pelarut kalium, angka-angka yang diikuti oleh huruf yang berbeda pada kolom yang sama menunjukan hasil yang berbeda nyata pada DMRT taraf 5\%.

Tabel 2. Pengaruh inokulasi pupuk hayati dan biokompos terhadap karakteristik kimia tanah

\begin{tabular}{clllccc}
\hline Perlakuan & $\mathrm{N}(\%)$ & $\mathrm{P}(\%)$ & $\mathrm{K}(\%)$ & $\mathrm{pH} \mathrm{H}_{2} \mathrm{O}$ & $\mathrm{pH} \mathrm{KCl}$ & C-organik (\%) \\
\hline $\mathrm{V}_{1} \mathrm{P}_{1}$ & $0,57 \mathrm{a}$ & 0,54 & $1,11 \mathrm{a}$ & 5,10 & 4,83 & 2,24 \\
$\mathrm{~V}_{1} \mathrm{P}_{2}$ & $0,54 \mathrm{a}$ & 0,35 & $0,84 \mathrm{~b}$ & 5,12 & 4,75 & 2,11 \\
$\mathrm{~V}_{1} \mathrm{P}_{3}$ & $0,44 \mathrm{~b}$ & 0,38 & $0,77 \mathrm{bc}$ & 5,15 & 4,66 & 2,39 \\
$\mathrm{~V}_{1} \mathrm{P}_{4}$ & $0,43 \mathrm{~b}$ & 0,34 & $0,84 \mathrm{~b}$ & 5,21 & 4,89 & 2,56 \\
$\mathrm{~V}_{2} \mathrm{P}_{1}$ & $0,50 \mathrm{ab}$ & 0,36 & $1,09 \mathrm{a}$ & 5,39 & 4,91 & 2,55 \\
$\mathrm{~V}_{2} \mathrm{P}_{2}$ & $0,46 \mathrm{~b}$ & 0,45 & $1,05 \mathrm{a}$ & 5,10 & 4,79 & 2,55 \\
$\mathrm{~V}_{2} \mathrm{P}_{3}$ & $0,45 \mathrm{~b}$ & 0,38 & $0,77 \mathrm{bc}$ & 4,80 & 4,67 & 2,13 \\
$\mathrm{~V}_{2} \mathrm{P}_{4}$ & $0,42 \mathrm{~b}$ & 0,29 & $0,63 \mathrm{c}$ & 4,93 & 4,30 & 2,48 \\
$\mathrm{~V}_{3} \mathrm{P}_{1}$ & $0,59 \mathrm{a}$ & 0,33 & $1,05 \mathrm{a}$ & 4,90 & 4,53 & 2,49 \\
$\mathrm{~V}_{3} \mathrm{P}_{2}$ & $0,54 \mathrm{a}$ & 0,37 & $0,49 \mathrm{c}$ & 5,04 & 4,80 & 2,51 \\
$\mathrm{~V}_{3} \mathrm{P}_{3}$ & $0,28 \mathrm{c}$ & 0,39 & $0,56 \mathrm{c}$ & 4,94 & 4,75 & 2,68 \\
$\mathrm{~V}_{3} \mathrm{P}_{4}$ & $0,26 \mathrm{c}$ & 0,38 & $0,49 \mathrm{c}$ & 4,80 & 4,72 & 2,51 \\
\hline
\end{tabular}

Keterangan: angka-angka yang diikuti oleh huruf yang sama pada kolom yang sama berbeda tidak nyata pada DMRT taraf 5\%. 
Tabel 3. Pengaruh inokulasi pupuk hayati dan biokompos terhadap karakter pertumbuhan tanaman padi gogo

\begin{tabular}{ccccc}
\hline Perlakuan & $\begin{array}{c}\text { Tinggi tanaman } \\
(\mathrm{cm})\end{array}$ & $\begin{array}{c}\text { Jumlah anakan } \\
\text { total }\end{array}$ & $\begin{array}{c}\text { Bobot kering } \\
\text { tajuk }(\mathrm{g})\end{array}$ & $\begin{array}{c}\text { Bobot kering } \\
\text { akar }(\mathrm{g})\end{array}$ \\
\hline $\mathrm{V}_{1} \mathrm{P}_{1}$ & $106,32 \mathrm{a}$ & $17,5 \mathrm{~b}$ & 54,80 & 34,60 \\
$\mathrm{~V}_{1} \mathrm{P}_{2}$ & $100,33 \mathrm{a}$ & $11,5 \mathrm{~d}$ & 42,30 & 30,20 \\
$\mathrm{~V}_{1} \mathrm{P}_{3}$ & $100,30 \mathrm{a}$ & $16,5 \mathrm{~b}$ & 34,90 & 17,80 \\
$\mathrm{~V}_{1} \mathrm{P}_{4}$ & $102,31 \mathrm{a}$ & $12,0 \mathrm{~cd}$ & 26,20 & 18,20 \\
$\mathrm{~V}_{2} \mathrm{P}_{1}$ & $55,17 \mathrm{bc}$ & $26,5 \mathrm{a}$ & 30,60 & 16,80 \\
$\mathrm{~V}_{2} \mathrm{P}_{2}$ & $56,17 \mathrm{bc}$ & $23,5 \mathrm{ab}$ & 30,20 & 19,40 \\
$\mathrm{~V}_{2} \mathrm{P}_{3}$ & $48,14 \mathrm{c}$ & $27,5 \mathrm{a}$ & 34,90 & 28,10 \\
$\mathrm{~V}_{2} \mathrm{P}_{4}$ & $68,20 \mathrm{~b}$ & $24,0 \mathrm{a}$ & 27,00 & 17,40 \\
$\mathrm{~V}_{3} \mathrm{P}_{1}$ & $49,10 \mathrm{c}$ & $17,5 \mathrm{~b}$ & 32,50 & 22,90 \\
$\mathrm{~V}_{3} \mathrm{P}_{2}$ & $68,20 \mathrm{~b}$ & $18,0 \mathrm{~b}$ & 36,30 & 24,60 \\
$\mathrm{~V}_{3} \mathrm{P}_{3}$ & $60,18 \mathrm{~b}$ & $19,5 \mathrm{~b}$ & 16,30 & 9,60 \\
$\mathrm{~V}_{3} \mathrm{P}_{4}$ & $68,20 \mathrm{~b}$ & $13,0 \mathrm{~cd}$ & 35,00 & 19,30 \\
\hline
\end{tabular}

Keterangan: angka-angka yang diikuti oleh huruf yang sama pada kolom yang sama berbeda tidak nyata pada DMRT taraf 5\%.

Keberadaan mikroba dalam tanah berhubungan erat dengan kadar hara jaringan tanaman. Semakin tinggi populasi mikroba tanah maka kadar hara jaringan semakin meningkat. Kadar hara dalam jaringan tanaman menunjukan kadar hara aktual yang diserap oleh tanaman. Semakin tinggi kadar hara tanaman mengindikasikan semakin tinggi ketersediaan unsur hara hara dalam tanah yang mampu terserap oleh tanaman. Menurut Stebbins and Wilder (2003) melaporkan bahwa konsentrasi hara daun dapat digunakan sebagai petunjuk untuk menentukan status hara tanaman yang polanya berhubungan langsung dengan pertumbuhan dan produksi tanaman. Hasil analisis varian menunjukkan bahwa perlakuan memberikan pengaruh terhadap kadar hara tanaman yang meliputi $\mathrm{N}$ dan $\mathrm{K}$, namun berpengaruh tidak nyata terhadap kadar hara $\mathrm{P}$, nilai $\mathrm{pH} \mathrm{KCl}, \mathrm{pH} \mathrm{H}_{2} \mathrm{O}$, dan kadar $\mathrm{C}$ organik tanah.

Aplikasi inokulan ganda mikroba pelarut $\mathrm{P}(\mathrm{pf})+$ mikroba pelarut $\mathrm{K}+$ mikroba pemfiksasi $\mathrm{N}$ pada pertanaman padi gogo varietas Inpago 10 menghasilkan kadar $\mathrm{N}$, dan $\mathrm{K}$ tertinggi secara berturutturut $0,57 \%$, dan $1,1 \%$. Hal ini berkaitan erat dengan populasi mikroorganisme yang mampu membantu tanaman dalam menyerap N, dan K. Pada Tabel 1 terlihat bahwa aplikasi inokulan ganda mikroba pelarut $\mathrm{P}(\mathrm{pf})+$ mikroba pelarut $\mathrm{K}+$ mikroba pemfiksasi $\mathrm{N}$ pada pertanaman padi gogo varietas Inpago 10 menghasilkan populasi Azotobakter dan bakteri pelarut K lebih tinggi dibandingkan dengan perlakuan lainnya. Menurut Hindersah dan Simarmata (2004) dan Syam'un et al. (2012) bahwa Azotobacter sp. adalah salah satu spesies rizobakteri pemfiksasi dinitrogen yang 
mengubah dinitrogen menjadi amonium melalui reduksi elektron dan protonasi gas dinitrogen. Disisi lain menurut Basak and Biswas (2009) bahwa penggunaan BPK meningkatkan biomassa hasil dan penyerapan kalium. Oleh karena itu semakin tinggi populasi Azotobakter dan bakteri pelarut $\mathrm{K}$ maka semakin tinggi tanaman menyerap unsur $\mathrm{N}$, dan $\mathrm{K}$.

Secara umum hasil penelitian menunjukkan bahwa inokulan pupuk hayati yang digunakan mampu meningkatkan hara tanaman dibandingkan dengan aplikasi pupuk sintetik. Hal ini terlihat dari Tabel 2 yang menunjukkan bahwa kadar hara tanah terutama $\mathrm{N}$ dan $\mathrm{K}$ dengan aplikasi inokulan ganda mikroba pelarut $\mathrm{P}(\mathrm{pf})+$ mikroba pelarut $\mathrm{K}+$ mikroba pemfiksasi $\mathrm{N}$, inokulan ganda mikroba pelarut $\mathrm{P}(\mathrm{fma})+$ mikroba pelarut $\mathrm{K}+$ mikroba pemfiksasi N] lebih tinggi dibandingkan dengan aplikasi pupuk sintetik dosis rekomendasi pada semua varietas yang diuji.

Keberadaan mikroba tanah menjadi salah satu faktor yang mempengaruhi pertumbuhan tanaman berupa perbaikan kualitas kesuburan tanah. Hasil penelitian menunjukkan bahwa perlakuan inokulan ganda mikroba pelarut $\mathrm{P}(\mathrm{pf})+$ mikroba pelarut $\mathrm{K}+$ mikroba pemfiksasi $\mathrm{N}$ pada pertanaman varietas Inpago 10 menghasilkan tinggi tanaman tertinggi yaitu 106,32 cm, sedangkan jumlah anakan produktif dihasilkan oleh inokulan ganda mikroba pelarut $\mathrm{P}(\mathrm{pf})+$ mikroba pelarut $\mathrm{K}$ + mikroba pemfiksasi $\mathrm{N}$ pada pertanaman varietas Serantan yaitu 26,5 anakan (Tabel 3). Hal tersebut kaitannya dengan kemapuan mikroba dalam membantu tanaman menyerap unsur hara terutama $\mathrm{N}$, $\mathrm{P}$, dan $\mathrm{K}$ sehingga pertumbuhan tanaman meningkat.

\section{KESIMPULAN}

Aplikasi pupuk hayati maupun biokompos yang ditanami padi gogo varietas Inpago 10 mampu meningkatkan karakter biologi dan kimia tanah. Padi gogo varietas Serantan dengan aplikasi inokulan ganda mikroba pelarut $\mathrm{P}+$ mikroba pelarut $\mathrm{K}+$ mikroba pemfiksasi $\mathrm{N}$ menunjukan hasil tinggi pada jumlah anakan dengan tinggi tanaman rendah.

\section{DAFTAR PUSTAKA}

Abdurachman, A., Dariah, A., Mulyani, A. 2008. Strategi dan teknologi pengelolaan lahan kering mendukung pengadaan pangan nasional. J. Litbang Pert. 27(2): 43-49.

Ashraf, M. and P.J.C. Harris. 2004. Potential biochemical indicators of salinity tolerance in plants. Plant Science, 166(1): 3-16.

Astuti,Y.W., L.U. Widodo dan I. Budisantosa. 2013. Pengaruh bakteri pelarut fosfat dan bakteri penambat nitrogen terhadap pertumbuhan tanaman tomat pada tanah masam. Biosfera A Scientific Journal. 30(3): 134-142. 
Aquilanti, L., Favilli, F. and Clementi, F. 2004. Comparison of different strategies for isolation and preliminary identification of Azotobacter from soil samples. Soil Biol. Biochem. 36(9): 1475-1483.

Bais, H.P., Weir, T.L., Perry, L.G., Gilroy, S. and J.M. Vivanco. 2006. The role of root exudates in rhizosphere interactions with plants and other organisms. Annu Rev Plant Biol, 57: 233-266.

Basak, B.B. and D.R. Biswas. 2009. Influence of potassium solubilizing microorganism

(Bacillus mucilaginosus) and waste mica on potassium uptake dynamics by Sudan grass (Sorghum vulgare Pers.) grown under two Alfisols. Plant Soil, 3(17): 235-255.

Bertham, Y.H. 2002. Respon tanaman kedelai (Glycine max (1) Merill ) terhadap pemupukan fosfor dan kompos jerami pada tanah Ultisol. J. Ilmu-Ilmu Pertanian Indonesia. 4(2): 78-83.

Bertham, Y.H., M. Handajaningsih dan D.W. Ganefianti. 2013. Uji coba budidaya cabai organik di lahan pesisir bengkulu. Prosiding Semirata Bidang Ilmu-Ilmu Pertanian Fakultas Pertanian UNTAN dan BKS PTN Wilayah Barat. 12: 99-106.

Bertham, Y.H., A.D. Nusantara, H. Pujiwati dan A. Andani. 2016 - 2018. Pemberdayaan masyarakat kawasan pesisir lautan berbasis budidaya kedelai hayati dan organik. Laporan Penelitian Hibah Kompetensi 3 tahun. Universitas Bengkulu, Bengkulu.

Bertin, C., Yang, X and L.A. Weston. 2003. The role of root exudates and allelochemicals in the rhizosphere. Plant Soil, 256(1): 67-83.

Budiharsono, S. 2001. Teknik analisis pembangunan wilayah pesisir dan lautan. Pradnya Paramita. Jakarta.
Chiu, H., Peters J.W., Lanzilotta, W.N., Ryle, M.J., Seefeldt, L.C., Howard J,B., Rees, D.S. 2001. MgATP-bound and nucleotide-free-structure of a nitrogenase protein complex between the leu 127 delta-Fe-protein and the MoFe-protein. Biochemistry, 40(3): 641-650.

Don, N, T. and C.N. Diep. 2014. Isolation, characterization and identification of phosphate and potassium solubilizing bacteria from weathered materials of granite rock mountain, That Son, an Giang province, Vietnam. Americ $J$ Life Sci. 2(5): 282-291.

Doornbos, R.F., van Loon, L.C and P. A. H. M. Bakker. 2012. Impact of root exudates and plant defense signaling on bacterial communities in the rhizosphere. A review. Agron. Sustain. Dev. 32: 227-243.

Gorham, J. 2007. Sodium. In Barker, A.V and D.J Pilbeam (eds). Handbook of Plant Nutrition. Taylor \& Francis. p. 569-575.

Hu, X., J. Chen and J.Guo. 2006. Two phosphate and potassium solubilizing bacteria isolated from Tianmu Mountain, Zhejiang, China. World J. Microbiol Biotechnol. 22(9): 983990.

Jones, R., W, Sun, C.S. Tang, F.M. Robert. 2004. Phytoremediation of petroleum hydrocarbons in tropical coastal soils. II. Microbial response to plant roots and contaminant. Environ Sci Pollut Research, 11:340-346.

Kementerian Pertanian Republik Indonesia. 2017. Statistik pertanian. Pusat Data dan Sistem Informasi Pertanian., Kementerian Pertanian Republik Indonesia. Jakarta.

Keneni, A., Assefa, F and Prabu, P. C. 2010. Isolation of phosphate solubilizing bacteria from the rhizosphere of Faba Bean of Ethiopia and their abilities on 
solubilizing insoluble phosphates. J. Agr. Sci. Tech. 12(1): 79-89.

Nurmegawati dan W. Wibawa. 2012. Adaptasi varietas unggul baru pada lahan rawa pasang surut di Provinsi Bengkulu. Balai Pengkajian Teknologi Pertanian Bengkulu. Bengkulu.

Nusantara, A.D., Y.H. Bertham dan B.G. Murcitro. 2018. Uji tumbuh edamame dengan memanfaatkan potensi pupuk hayati dalam meningkatkan pertumbuhan produktivitas edamame di kawasan pesisir. Laporan Penelitian Unggulan Universitas. Universitas Bengkulu, Bengkulu.

Oktaviani, Hasanah, dan Barus. 2014. Pertumbuhan kedelai (Glycine max L. Merrill) dengan aplikasi fungi mikoriza arbuskular (FMA) dan konsorsium mikroba. Jurnal Online Agroekoteknologi. 2(2): 905-918.

Purwaningsih, S. 2003. Isolasi, Populasi dan karakterisasi bakteri pelarut fosfat pada tanah dari Taman Nasional Bogani Nani Wartabone, Sulawesi Utara. J. Biologi. 3(1): 2231.
Simamora, R.M., Yulian, dan E. Turmudi. 2018. Penampilan 10 aksesi talas (Colocasio esculenta (L). Schott) di lahan pesisir Bengkulu. J. Ilmu-Ilmu Pertanian Indonesia. 20(1): 19-25.

Singh, G., D. R. Biswas, and T. S. Marwah. 2010. Mobilization of potassium from waste mica by plant growth promoting rhizobacteria and its assimilation by maize (Zea mays) and wheat (Triticum aestivum L). J Plant Nutr. 33(8): 1236-1251.

Sudaryono. 2001. Pengaruh pemberian bahan pengkondisi tanah terhadap sifat fisik dan kimia tanah pada lahan marginal berpasir. Jurnal Teknologi Lingkungan, 2(1): 106-112.

Syam'un, E. Kaimuddin dan A. Dachlan. 2012. Pertumbuhan vegetatif dan serapan tanaman $\mathrm{N}$ yang diaplikasi pupuk $\mathrm{N}$ anorganik dan mikroba penambat $\mathrm{N}$ non-simbiotik. J. Agrivigor, 11(2): 251-261.

Zuhry, E. dan F. Puspita. 2008. Pemberian cendawan mikoriza arbuskular (CMA) pada tanah podsolik merah kuning terhadap pertumbuhan dan produksi kedelai (Glycine $\max (\mathrm{L})$ Merill. J. Sagu. 7(2): 25-29. 